\title{
Assessment of renewable energy and emissions from domestic sewage treatment in Brazil
}

\author{
Fatima Aparecida de Morais Lino , Kamal Abdel Radi Ismail \\ Energy Department, Faculty of Mechanical Engineering, State University of Campinas, Barão Geraldo, Campinas, Brazil
}

\section{Email address:}

fatimalino@fem.unicamp.br (F. A. d. M. Lino)

\section{To cite this article:}

Fatima Aparecida de Morais Lino, Kamal Abdel Radi Ismail. Assessment of Renewable Energy and Emissions from Domestic Sewage Treatment in Brazil. International Journal of Energy and Power Engineering. Vol. 3, No. 5, 2014, pp. 254-260.

doi: 10.11648/j.ijepe.20140305.16

\begin{abstract}
With the growth of the world population, in recent decades, the generation of domestic sewage has increased. In Brazil about 28 million cubic meters of sewage are generated daily and needs to be collected and treated. This task has been one of the biggest challenges for municipal administrators. Disposition of domestic sewage without treatment is a risk to public health and environment. This paper presents scenarios for treatment of domestic sewage with energy recovery and minimization of environmental impacts based on the biodigestion and incineration with the objective of demonstrating to the public administrators the economic and environmental energy potential. The results show that the electrical energy from the biodigestion of sewage sludge is equivalent to the consumption of 1.5 million households and electricity resulting from incineration corresponds to consumption of 1.3 million homes while the emissions are about $0.875 \mathrm{MtCO}_{2}$ per year compared to $3.585 \mathrm{MtCO}_{2} /$ year released in the biological treatment. In addition, in both processes of treatments, it is possible to recover half of the volume of wastewater for reuse. In this way, adequate treatment of domestic sewage can protect the environment from the drastic charges of sewage while being a source of energy and water, which are indispensable assets for maintenance of life on the planet.
\end{abstract}

Keywords: Domestic Sewage, Wastewater, Biodigestion, Incineration, Energy, Emission

\section{Introduction}

Treatment of domestic sewage (DS) in Brazil is a problem that requires urgent solution considering that most of the sewage volume generated is discarded without treatment in water bodies. According to the 2010 census, $11 \%$ of urban households has DS flowing freely in the streets [1].

The discharge of untreated DS causes serious impacts on the environment and on public health. According to the World Health Organization, in 2008 about 2.5 million persons were fatal victims of diarrheic diseases. Of these about 1.5 million children of age less than 5 years were infected due to inadequate basic sanitation [2]. In Brazil, in 2010, these diseases infected in average 600 per 100,000 inhabitants. In addition to the impacts on health, there are others issues which are equally important and deserve a special attention.

Energy and water demands in Brazil are continuously growing due to population increase and industrial developments [3]. In most cases they are closely related since about $80 \%$ of the installed electric capacity is hydraulic. Weak rainy seasons and long dry periods usually have immediate impacts on available water reserves for energy generation and also on water supplies for human activities and survival.

The adequate treatment of DS enables water recovery for reuse and hence conserves water reserves, while the sludge can be incinerated to produce heat and electricity to supplement available energy. The ash after incineration can be reused for construction material, in the cement industry and other applications. Part of the sludge can be used also for composting to produce natural fertilizers. In this way adequate management of DS can solve definitively the public health and environment problems and at the same time can be used as a new source of renewable energy and water. The biological treatment of DS is also widely used in countries as Slovakia, Egypt, Sweden [4-6].

In this case, DS is dewatered and forwarded for biodigestion in anaerobic reactors for production of biogas. The collected water is treated for possible reuse, while the biogas is cleaned and combusted to produce heat and electricity. Therefore, this paper presents two DS treatment scenarios based on 
biodigestion and incineration with the objective of demonstrating to the Brazilian public authorities the treatment techniques used in some countries and the energy, economic and environmental potential gains contained in DS.

\section{Literature Review}

\subsection{Treatment of Domestic Sewage in Developed Countries}

The most common methods of treating DS used in developed countries include aerobic treatment plants and septic tanks. In USA approximately $20 \%$ of the DS is treated in septic tanks while the rest is collected and treated in aerobic treatment plants [7]. Table 1 shows percentage the urban population connected to DS network in seven countries.

Table 1. Population connected to DS network

\begin{tabular}{lc}
\hline Country & Population connected to DS network (\%) \\
\hline Germany & 97 \\
Netherlands & 99 \\
Japan & 76 \\
United States & 74 \\
Denmark & 90 \\
United Kingdom & 97 \\
Canada & 87 \\
\hline
\end{tabular}

Source: $[7,8]$.

\subsection{Collection, Treatment and Disposal of DS in Developing Country}

In developing and some developed countries, according to IPCC $[9,10]$, DS is collected by networks of closed or open channels and without any treatment is discharged into the nearest water bodies. Some coastal towns discharge their DS without any treatment into the ocean. According to UN/INWEH [11], the real situation in poor countries is dramatic. The major part of generated DS is not always collected and the treated volume is relatively small. In 2009, Cuba collected $35.9 \%$ of the generated DS and treated $24 \%$. In the same year, Venezuela collected $86 \%$ and treated only $23.8 \%$ [7].

\subsubsection{Domestic Sewage Treatment in Brazil}

In Brazil the DS generated is considered equal to the water consumption and it varies from region to another having national average of 162.6 1/inhab./day. The country treats $37.5 \%$ of the generated DS. In 2011, only 124 million inhabitants had their DS partially treated [12]. The volume of generated DS in 2008 was $28,249,154 \mathrm{~m}^{3} /$ day of which $12.304 .128 \mathrm{~m}^{3} /$ day was collected and only $8.460 .590 \mathrm{~m}^{3} /$ day received some type of treatment [13].

The most common methods of final disposition of DS in Brazil include DS aerobic treatment plants, septic tanks and rudimental septic tanks. This last is inadequate and provokes contaminations and diseases [2,13-14].

According to IBGE [13] about $30.5 \%$ of the 5565 municipalities dispose their DS without any treatment into rivers and lakes whose water is treated for human consumption, used for other necessities, irrigation and fish farms. Discharged DS contaminate these sources and makes its treatment relatively expensive. The organic load disposed into rivers is about 5500 tons DBO/day and is concentrated in highly populated regions [14] while the value of discharge limit established by the National Environmental Council (CONAMA) is less than or equal to $5 \mathrm{mg} / \mathrm{l}$. Current values found in the brazilian rivers are more than $20 \mathrm{mg} / \mathrm{l}$ [15].

According to the Water National Agency [14] water quality in $12 \%$ of a 148 monitored localities are extremely bad and $32 \%$ are in bad conditions. Obviously public health is the most impacted by the consumption of contaminated water and in case of inundations mixture of water and DS can aggravate the situation and spread diseases and contaminations.

\subsection{Treatment and Disposal of Domestic Sewage}

The treatment and disposition of DS are some of complicated problems which require adequate solutions integrating technical, economical, social and environment evaluation. In most of the cases the decision is locally and/or politically based [16-18]. The most common methods used include disposition into water bodies such as rivers, lakes and sea, landfilling, biological and thermal treatments.

\subsubsection{Landfill}

Disposition of sewage sludge in landfills is a common practice. About $40 \%$ of the sewage sludge generated in Europe is disposed in landfills [19]. This method has serious implications as reduction of the useful life of the landfill and the risk of producing leachate and soil contamination. An alternative way is to build a specific landfill according to engineering standards to dispose safely the sewage sludge. This option should be the last to be considered if there is no other use the sewage sludge as per example in composting or energy generation by incineration $[20,21]$.

\subsubsection{Biological Treatment}

The removal of organic matter in the sewage sludge can be achieved by either aerobic or anaerobic treatment. In the aerobic method the organic matter is oxidized to mineral products (organic composts) while in the anaerobic case the process is developed without oxidation. Both methods reduce the biological activities of sludge and consequently reduce its volume [22, 19].

The digested sewage sludge although has relatively low calorific value can be incinerated if there is no use for it as fertilizer. In this case the organic compost is transformed into fertilizer after maturation period.

The sewage sludge is usually rich in nutrients and can substitute chemical fertilizers for soil recovering [23]. The biogas is the principal product of the anaerobic digestion of organic solid and is generally composed of 50-75\% methane $\left(\mathrm{CH}_{4}\right)$ and $25-50 \%$ carbon dioxide $\left(\mathrm{CO}_{2}\right)$ and small amounts of other gases. The production rate of biogas is about 50-150 $\mathrm{m}^{3}$ of biogas / ton of sewage sludge [4].

\subsubsection{Incineration}

The main objective of the thermal treatment of DS sludge by incineration is to convert its energy content into heat and 
electricity and reduce its environment impacts.

In the incineration process the organic solid is converted into heat, carbon dioxide, water vapor and ash. The amount of heat released during incineration depends on the composition of the sewage sludge and determines the necessity or not to use auxiliary fuel to maintain the incineration process.

Sludge with high humidity content, $70-80 \%$ will require auxiliary fuel to maintain the flame temperature and hence the combustion process $[17,9,24]$.

Sewage sludge of calorific value varying between 3.5 $\mathrm{MJ} / \mathrm{kg}$ to $6.5 \mathrm{MJ} / \mathrm{kg}$ normally will not require auxiliary fuel.

Incineration is the option most used for treating sewage sludge in many developed countries. Belgium incinerates $70 \%$ of the sludge, Netherlands about $60 \%$ while Denmark and Germany incinerate about $40 \%[25,19]$.

As was seen, the inadequate treatment of DS brings serious implications and negative impacts on the ambient and public health. In Brazil, which is the fifth most populous country in the world, the issue of sanitation requires urgent solution of public power.

\section{Materials and Methods}

In this section the available technical data and the simplified models for the proposed scenarios for DS treatment are presented and discussed.

\subsection{Materials}

\subsubsection{Treatment Scenarios}

From the literature review, the most suitable routes are thermal and the biological routes. In the thermal route the DS is dewatered and the sludge is incinerated producing heat and electricity. The ash is reused for road paving and civil construction applications. The water is further treated to be reused.

In the biological treatment the DS is dewatered and the water for further treated for reuse. The sewage sludge is then prepared and pumped to the biological reactors to generate biogas for heat and electricity production.

Table 2. Technical data

\begin{tabular}{llll}
\hline Description & Reference value & Adopted value & Source \\
\hline Specific mass of $\mathrm{CO}_{2}\left(\mathrm{~kg} / \mathrm{m}^{3}\right)$ & 1.83 & 1.83 & {$[26]$} \\
$\mathrm{CO}_{2}$ due to incineration $\left(\mathrm{tCO}_{2} / \mathrm{TJ}\right)$ & $10-40$ & 25 & {$[27]$} \\
$\mathrm{GWP}$ of $\mathrm{CH}_{4}$ & 25 & 25 & {$[10]$} \\
$\mathrm{LCV}$ of $\mathrm{CH}_{4}\left(\mathrm{MJ} / \mathrm{m}^{3}\right) 1$ & 33.95 & 33,95 & {$[26]$} \\
Biogas production from sludge $\left(\mathrm{m}^{3} / \mathrm{kg}\right)$ & $0.8-1.1$ & 0.95 & {$[24]$} \\
Solid fraction in sludge $\left(\mathrm{kg} / \mathrm{m}^{3}\right)$ & $0.1-0.3$ & 0.2 & {$[24]$} \\
Auxiliary fuel for incineration $(\mathrm{kg} / \mathrm{t})$ & 8.0 & 8.0 & {$[28]$} \\
Emissions $(\mathrm{kg} \mathrm{CO} / \mathrm{kg} \mathrm{LPG})^{2}$ & 3.019 & 3.019 & {$[28]$} \\
$\mathrm{LCV}$ of biogas from sludge $\left(\mathrm{MJ} / \mathrm{m}^{3}\right)$ & $15-25$ & 20 & {$[29]$} \\
$\mathrm{Heat}$ content of incinerated sludge $(\mathrm{MJ} / \mathrm{kg})$ & $12.80-19.75$ & 16 & {$[24]$} \\
$\mathrm{LCV}$ of $\mathrm{LPG}(\mathrm{MJ} / \mathrm{kg})$ & $40.05-46.05$ & 40.05 & {$[26]$} \\
Water consumption $\left(\mathrm{m}^{3} / \mathrm{month}\right)^{3}$ & 17.1 & 17.1 & {$[12]$} \\
EE consumption $(\mathrm{MWh} / \mathrm{capita})^{4}$ & 0.604 & 0.604 & {$[30]$} \\
\hline
\end{tabular}

(1) Lower calorific value; (2) LPG - Liquefied Petroleum Gas; (3) Average Brazilian residence; (4) Electric energy

\subsubsection{Technical Data}

Table 2 presents technical data used in the calculations while the flow diagrams for the two routes together with equations used in the calculations are presented in section 3.2.

\subsection{Methods}

\subsubsection{Biological Treatment of Sewage Sludge}

The biogas production depends on the composition of the sludge (content of biodegradable mass) and the rigid control of the operational conditions. Rate of biogas production from sewage sludge, according to Table 2, has an average value of $0.2 \mathrm{~kg} / \mathrm{m}^{3}$. The biodegradable solid mass can be calculated from equation 1 .

Biodegradable solid mass in the sludge $=$ Solid fraction in sludge $\mathrm{x}$ Volume of treated sludge

Biogas generated from sludge biodigestion can be calculated from equation 2 .
Volume of generated biogas $=$ Production rate of biogas $\mathrm{x}$ Biodegradable solid mass

The biogas generated can be combusted to produce heat and generate electricity. The quantity of released heat depends on the calorific value of biogas which varies from 15 to $25 \mathrm{MJ} / \mathrm{m}^{3}$. The quantity of released heat can be calculated from equation 3 .

Energy released by biogas $=$ Volume of biogas $\mathrm{x}$ LCV of biogas

The electric energy generated from the biogas (equation 4) can be calculated by multiplication of the result of equation 3 by the thermal conversion efficiency $\eta$, assumed here as $30 \%$.

Electric energy generated from biogas = Energy released by biogas $\mathrm{x}$ thermal conversion efficiency

According to the MME [30-31] the energy consumption per capita in 2012 was $0.604 \mathrm{MWh}$ which corresponds to $0.1812 \mathrm{x}$ $10^{9} \mathrm{~J}_{\mathrm{el}}$. Consider that a typical Brazilian family is composed of 
3.5 members [3], the monthly electric energy consumption is then $0.6342 \times 10^{9} \mathrm{~J}_{\mathrm{el}}$. The generated electric energy can be sufficient for a number of residences to be calculated from equation 5

Number of residences $=$ Monthly electric energy generated /average residential consumption

Emissions released during the combustion of biogas can be calculated by equations 6 and 7 where equation 6 represents the chemical reaction formula for $\mathrm{CH}_{4}$. From this equation it is clear that the amount of $\mathrm{CO}_{2}$ produced is equal to the quantity of combusted $\mathrm{CH}_{4}$. Hence the total amount of $\mathrm{CO}_{2}$ released is equal to the sum of amount of collected $\mathrm{CH}_{4}$ and $\mathrm{CO}_{2}$ originally present in the biogas. The emissions can be calculated from equation 7

$$
\mathrm{CH}_{4}+2 \mathrm{O}_{2}=\mathrm{CO}_{2}+2 \mathrm{H}_{2} \mathrm{O}
$$

$\mathrm{CO}_{2}$ emissions due to the combustion of collected biogas = Quantity of collected biogas

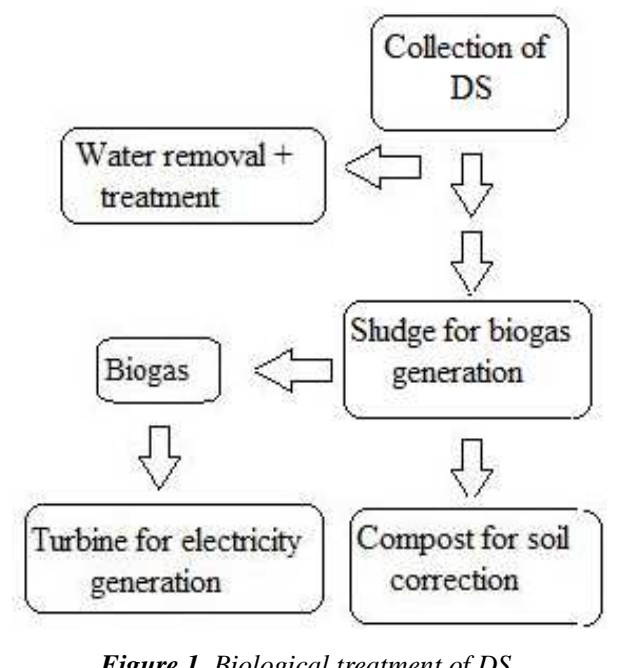

Water from dewatering sewage sludge can be treated for reuse. The amount of water possibly recoverable is assumed to be $50 \%$ of the consumed water. Hence by knowing the average water consumption of a typical family it is possible to estimate the number of residences which can be attended by the recovered water from Equation 8.

Number of residences which can be attended by the recovered water $=$ Volume of daily recovered water $\div$ daily average water consumption of a residence

The biodigested material can be used for soil correction or treated further for use as fertilizer.

\subsubsection{Thermal Treatment of Sludge}

As in the previous case the collected sewage is dewatered and the separated water is further treated for reuse as in Figure 2. The amount considered for reuse is $50 \%$. The sludge is thickened and pumped to the incineration plant.

The mass of solids in the sewage sludge can be determined by using equation 1 . The energy content of the sewage sludge depends on its composition. Normally there is a need for auxiliary fuel to start and maintain incineration and in the present case LPG was used. Energy resulting from incineration of sewage sludge can be calculated from equation 9 .

Energy released by incineration of sewage sludge $=$ Mass of solids x Energy content of sewage sludge

Knowing the rate of consumption of LPG during the incineration process per ton of sewage sludge (usually determined experimentally), the total amount of consumed LPG is calculated from equation 10 .

Total amount of consumed LPG $=$ Mass to be incinerated $\mathrm{x}$ Rate of consumption of the auxiliary fuel

Energy released by the combustion of LPG can be calculated from equation 11 .

Energy released by the auxiliary fuel = Mass of auxiliary fuel $\mathrm{x}$ LCV of the auxiliary fuel

The net amount of energy released during the incineration process is the difference between energy released by the incinerated material and energy released by the auxiliary fuel as in equation 12 .

Net energy released during incineration $=$ Energy released by sewage sludge - Energy released by the auxiliary fuel

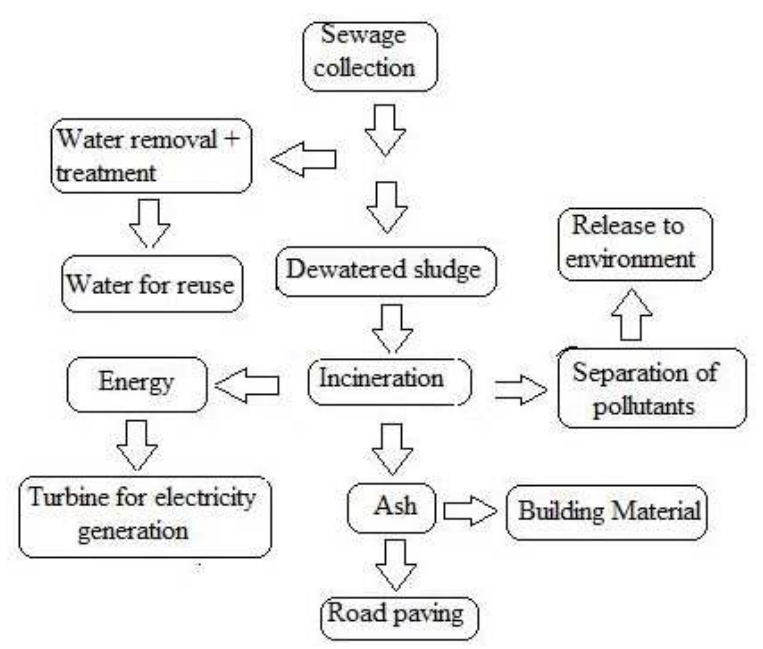

Figure 2. Incineration of $D S$.

The hot gases can be used to generate steam and electricity with conversion efficiency of about $30 \%$, as in equation 13

Generated electric energy = Net energy released by incineration $\mathrm{x}$ Conversion efficiency

The combustion gases after leaving the boiler still have thermal energy which can be recovered for heating combustion air, produce hot water and drying sewage sludge to improve the overall thermal efficiency of the system. The relatively cold gases are cleaned and the pollutants are removed before releasing to the atmosphere.

Emissions resulting from incineration of sludge and the 
combustion of LPG can be calculated from the emissions factors presented in Table 2.

The quantity of $\mathrm{CO}_{2}$ emitted due to the combustion of LPG and incineration of sewage sludge can be calculated from equations 14 and 15 .

Emissions of $\mathrm{CO}_{2}$ from the combustion of $\mathrm{LPG}=$ Emission factor x LPG mass

Emissions of $\mathrm{CO}_{2}$ from the incineration of sewage sludge $=$ Emission factor $\mathrm{x}$ mass of sewage sludge

Total emissions are the sum of the results from equations 14 and 15 . Ash resulting from incineration can be reused for road paving, cement industry and other applications.

\section{Results and Discussion}

The flow charts and associated set of equations are used for assessing the energy, emissions and financial benefits from each of the proposed scenarios for treating sewage sludge. The results are presented in Table 3.

The results of the biological route show that $5.6 \mathrm{Mt} /$ day of sewage sludge produced by the urban population when subjected to anaerobic digestion produce about $5.4 \mathrm{Mm}^{3}$ biogas / day which when converted to electric energy produce monthly about $268 \mathrm{GWh}$ sufficient for 1,5 million residences. The $\mathrm{CO}_{2}$ emissions due to the combustion of biogas are about $3.6 \mathrm{MtCO}_{2} /$ year. The recovered water of about $14 \mathrm{Mm}^{3} /$ day is sufficient for about 25 million residences.
The results of the incineration route show that incinerating about 5.6 Mt/day of sewage sludge can generate $221 \mathrm{GWh}$ sufficient for 1.2 million residences and generate about 0.875 $\mathrm{MtCO}_{2}$ /year. The recovered water of about $14 \mathrm{Mm}^{3} /$ day is sufficient for about 25 million residences.

It is important to observe that the biological treatment system can reduce the volume of sewage sludge by about 20 to $25 \%$ and the digested matter can be stabilized and used as natural fertilizer or for soil correction. On the other hand incineration reduces the mass of sewage sludge to about $10 \%$ and ash can be reused for road paving and fabrication of bricks and other uses.

Adequate treatment of DS results into a number of benefits including the electric energy generated which can reduce the demand for new hydraulic energy plants. In addition water bodies such as rivers, lakes and ocean will be free of the sewage discharged continuously with little or without any treatment causing serious impacts on the ecosystem and public health. Another important benefit is the recovered water which after adequate treatment can be reused in industry, irrigation, commercial and other residential applications and contributes to the sustainability of cities.

As was mentioned earlier adequate treatment of DS can reduce contamination of soil and water resources also reduce public expenditure on hospitalization and combat programs against diseases originated from poor sanitary conditions and intensive and expensive water treatment for human use.

Table 3. Proposals for treatment of DS in Brazil

\begin{tabular}{|c|c|c|}
\hline Description & Biological treatment with biogas recovery & Incineration \\
\hline Sewage generated $\left(\mathrm{m}^{3} /\right.$ day $)$ & $28,249,154$ & $28,249,154$ \\
\hline Sludge for biodigestion or incineration ( $t /$ day) & $5,649,831$ & $5,649,831$ \\
\hline Biogas generated ( $\mathrm{m}^{3} /$ day $)$ & $5,367,339$ & \\
\hline Energy generated from biogas ( $\mathrm{J} /$ day) & $128.816 \times 10^{12}$ & \\
\hline Energy generated in the incineration ( $\mathrm{J} /$ day) & & $90.397 \times 10^{12}$ \\
\hline Energy generated from biogas (J/month) & $3220.4 \times 10^{12}$ & \\
\hline Energy generated in the incineration ( $\mathrm{J} / \mathrm{month})$ & & $2711,9 \times 10^{12}$ \\
\hline Energy generated from biogas $\left(\mathrm{J}_{\mathrm{el}} /\right.$ month $)$ & $966,12 \times 10^{12}$ & \\
\hline Energy generated from biogas (GWh mensal) & 268,37 & \\
\hline Net energy of incineration $(\mathrm{J} /$ day $)$ & & $88.587 \times 10^{12}$ \\
\hline Net energy of incineration $\left(\mathrm{J}_{\mathrm{el}} /\right.$ day $)$ & & $26.576 \times 10^{12}$ \\
\hline Net energy of incineration $\left(\mathrm{J}_{\mathrm{el}} /\right.$ month $)$ & & $797.283 \times 10^{12}$ \\
\hline Energy generated in the incineration (GWh month) & & 221.47 \\
\hline Number of residence that can be satisfied & $1,523,368$ & $1,257,143$ \\
\hline Emission ( $\mathrm{t} \mathrm{CO}_{2} /$ day) & 9,822 & $2,396.38$ \\
\hline Emission (Mt $\mathrm{CO}_{2} /$ year) & 3.585 & 0.875 \\
\hline Recuperated water for reuse ( $\mathrm{m}^{3} /$ day) & $14,124,577$ & $14,124,577$ \\
\hline Number of residence that can be satisfied & $24,823,510$ & $24,823,510$ \\
\hline
\end{tabular}

One must recognize that incineration of DS is not practiced in Brazil because of risks of infectious diseases, cancer and pollution issues. The present technological situation and available technologies for pollution control is completely different from the situation years ago. Incineration in Europe, USA and Japan is a well accepted practice for treating solid waste and sewage involving no risks of pollution and ambient contamination. In the case of Brazil the technology is new and it was usually associated with dramatic and fancy stories. For this reason a special attention is needed. The implementation of incineration must be well planned supported by adequate public policies and intensive awareness campaigns. Also participation of the private sector in these activities and financing sanitation projects is very important. 


\section{Conclusions}

The results from the proposed biological and thermal scenarios show environment and energy gains minimize impacts on public health and reduction of contamination of soil and bodies water. The recovered water after adequate treatment can be used for industrial, commercial and residential applications alleviating demands for new treated water and possible shortage during dry seasons. The digested organic matter from the biological treatment can be reused as fertilizer or incinerated to produce heat and electricity. The ash can be used for soil filling and road paving among other uses.

Brazil as a developing country needs to establish the necessary adequate priorities concerning sanitation services which are citizens right constitutionally secured and fundamental for improving life quality of the population. To achieve these objectives there must be a strong and determined political will associated with well engineering sanitation projects.

\section{Acknowledgements}

The authors wish to thank the CNPQ for the doctorate scholarship for the first author and for the PQ Research Grant for the second author.

\section{References}

[1] Instituto Brasileiro de Geografia e Estatística, IBGE, "Atlas do Censo demográfico 2010”. Rio de Janeiro, BR, 2013.

[2] WHO/UNICEF. "Progress on sanitation and drinking-water", Update. World Health Organization and UNICEF, France, 2013.

[3] IBGE/PNAD, "Síntese dos indicadores 2011" Instituto Brasileiro de Geografia e Estatística- Pesquisa nacional por amostra de domicílios, Rio de Janeiro, 2012.

[4] I. Bodík and M. Kubaská, "Energy and sustainability of operation of a wastewater treatment plant". Environment Protection Engineering, vol..39, no.2, 2013.

[5] M. R. Ghazy, T. Dockhorn and N. Dichtl, "Economic and environmental assessment of sewage sludge treatment processes application in Egypt", Fifteenth International Water Technology Conference, IWTC-15. Alexandria, Egypt, 2011.

[6] G. Petersen, "Life Cycle Assessment of four sludge disposal routes", Master Thesis, Environment Systems Analysis, Goteborg, Sweden, 2001.

[7] UNSTAT, "Environmental indicators. Population connected to wastewater collecting systems", United Nation Statistic Division, 2011, http://unstats.un.org/unsd/environment/wastewater.htm

[8] OECD, "Environment at a glance 2013" OECD Indicators: Wastewater treatment. http://www.oecd.org/oecddirect/

[9] IPCC, "Climate Change: Mitigation". Contribution of Working Group III to the Fourth Assessment Report of the Intergovernmental Panel on Climate Change. Cambridge University Press, Cambridge, United Kingdom and New York,
NY, USA, 2007.

[10] IPCC, "Guidelines for National Greenhouse by Gas Inventories", Intergovernmental Panel on Climate Change,.vol.5, Waste, 2006.

[11] UNU/INWEH, "World lacks data on wastewater reuse: rising reuse of wastewater in forecast but world lacks data on 'a massive potential Resource", United Nations University / Institute for Water, Environment and Health, 2013, http://inweh.unu.edu/rising-reuse-wastewater/

[12] MCidades, "Diagnóstico dos Serviços de Água e Esgoto 2011", Ministério das Cidades/SNSA/ SNIS, Brasília, BR, 2013.

[13] Instituto Brasileiro de Geografia e Estatística, IBGE, Atlas de Saneamento, 2011. http://www.ibge.gov.br/home/estatistica/populacao/atlas _saneamento/default_zip.shtm

[14] ANA, "Conjuntura dos recursos hídricos no Brasil", Informe 2013, Agência Nacional das Águas, Brasília, BR, 2013.

[15] MMA, "Política de águas e educação ambiental: processos dialógicos e formativos em planejamento e gestão de recursos hídricos", Organizadores: Franklin de Paula Junior e Suraya Modaelli, 3.ed., Ministério do Meio Ambiente, MMA/SRHU, Brasília, BR, 2013.

[16] G. Tchobanoglous, H. Theisen and S. A. Vigil, "Integrated Solid Waste Management, Engineering Principles and Management Issues”, McGraw-Hill, New York, 1993.

[17] P. J. Reddy, "Municipal solid waste management: processing, energy recovery, global examples", BS Publications, India, 2011.

[18] F. A. M. Lino and K. A. R. Ismail, "Alternative treatments for the municipal solid waste and domestic sewage in Campinas, Brazil", Resources, Conservation and Recycling, vol. 81, pp. 24-30, 2013.

[19] EC, European Commission, "Integrated pollution prevention and control". Reference document on the best available techniques for waste incineration. 2006.

[20] MMA, "Módulo específico: licenciamento ambiental de Estações de tratamento de Esgoto e aterros sanitários", Ministério do Meio Ambiente, Brasília, BR, 2009.

[21] H. Tammemagi, "The waste crisis: Landfills, incinerators and the search for a sustainable future".Oxford University Press New York, USA, 1999.

[22] F. R. Spellman, "Handbook of water and wastewater treatment plant operations", Lewis Publishers CRC Press Company, 2003.

[23] Milieu, "Environmental, economic and social impacts of the use of sewage sludge on land", Interim report prepared by Milieu Ltd., WRC and RPA, 2008.

[24] I. S. Turovskiy, P. K. Mathai, "Wastewater Sludge Processing". John Wiley \& Sons, Inc. 2006.

[25] ISWA, "Waste-to-energy: state of the art report", International Solid Waste Association Statistic, $6^{\text {th }}$ edition, 2012.

[26] J. W. Rose and J. R. Cooper, "Technical data on fuels", 7th edition, The British National Committee, London. 1977.

[27] S. Monni, R. Pipatti, A. Lehtilä, I. Savolainen, S. Syri, "Global climate change mitigation scenarios for solid waste management", VTT publications, 603, ESPOO, 2006. 
[28] MCT, "Projeto Usina Verde: Incineração de resíduos sólidos urbanos, com carga de composição similar ao RDF, evitando emissão de metano e promovendo geração de eletricidade para autoconsumo", Brasília: Ministério da Ciência e Tecnologia, MCT, 2008 , http://www.mct.gov.br/index.php/content/view/581778/.

[29] W.R. Niessen, "Combustion and Incineration Processes". 3rd Edition: Marcel Dekker, Inc. New York, USA, 2002.
[30] MME, "Anuário Estatístico de energia elétrica 2012", Ministério de Minas e Energia, 258p. BR, 2012, http://www.epe.gov.br/AnuarioEstatisticodeEnergiaEletr ica/20120914_1.pdf

[31] F. A. M. Lino, "Proposta de aproveitamento do potencial energético do resíduo sólido urbano e do esgoto doméstico com minimização dos impactos ambientais", Doctorate Thesis, State University of Campinas, 2014. 